\title{
Circular RNA: features, functions and their correlation with diseases especially cancer
}

\author{
Mohammad Reza Noori-Daloii ${ }^{1}$, Sima Emadi Allahyari ${ }^{2}$ \\ ${ }^{1}$ Professor, PhD of Medical Molecular Genetics, Department of Medical Genetics, School of Medicine, Tehran \\ University of Medical Sciences, Tehran, Iran \\ ${ }^{2}$ MSC student of Human Genetics, Department of Medical Genetics, School of Medicine, Tehran University of Medical \\ Sciences, Tehran, Iran
}

\begin{abstract}
In early 2012, the world of science saw a fascinating discovery called circular RNA as a transcription product of thousands of genes in mice and humans. These circular RNAs have recently been grouped as the encoding RNA in an independent group that their remarkable difference with other RNAs is that these RNAs are not linear, in which two ends connect with a covalent connection creating a loop-shaped structure. These molecules play a role in regulating the expression of genes in mammals, and also, unlike other RNAs, they are very stable. These RNAs are created quite differently by means of a mechanism called back splicing. In this mechanism, in a molecule of RNA, axons or lariat- shaped introns are bonded at two ends of '3 and '5 with a covalent bond, creating circular structures that, unlike other common RNAs in the cytoplasm, are very stable. The circular RNAs act as mRNA sponge and form a set of RNA and protein that engage in transcription regulation by binding to RNA-related proteins. This suggests that these RNAs regulate gene expression at the transcriptional level and then they react by miRNAs. In fact, those circular RNAs that play a role in regulating the function of miRNAs also play a role in the onset and progression of the cancer. In tumor tissues, circular RNAs are reduced in comparison with normal tissues, and this may be for reasons like error occurs in the back splicing mechanism, degradation by unregulated miRNAs or increased cell proliferation. Recently circular RNAs have been identified in exosomic studies and in the movement of chromosomes in cancers, and there is found that the incorrect and abnormal attachment of these types of RNAs is related to drug resistance. Although it is thought that circular RNAs are non-coding, some of them are translated into functional proteins. So far, there are many unknowns about circular RNAs and the mechanism for regulating the expression of genes by them, but there is a lot of evidence to convince us that they will soon be used as biomarkers to diagnose diseases and therapeutic targets for cancers.
\end{abstract}

Keywords: ncRNA, circRNA, Cancer, Diagnosis, Prognosis.

Cited as: Noori-Daloii MR, Emadi Allahyari S. Circular RNA: features, functions and their correlation with diseases especially cancer. Medical Science Journal of Islamic Azad University, Tehran Medical Branch 2019; 29(3): 191-202.

Correspondence to: Mohammad Reza Noori-Daloii

Tel: +9821 88953005

E-mail: nooridaloii@sina.tums.ac.ir

ORCID ID: 0000-0002-9044-9842

Received: 16 Apr 2019; Accepted: 5 May 2019 
مجله علوم يزشكى دانشگاه آزاد اسلامى

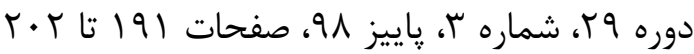

\section{هاى حلقوى: ويزگى ها،كاركردها و ارتباط آنها با بيمارىها به ويزه سرطان}

\section{محمدرضا نورى دلوئى'، سيما عمادى اله يارى'}

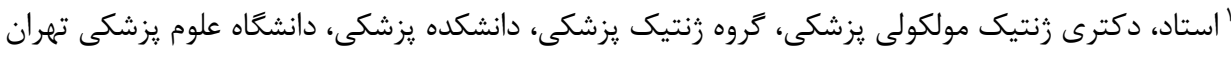

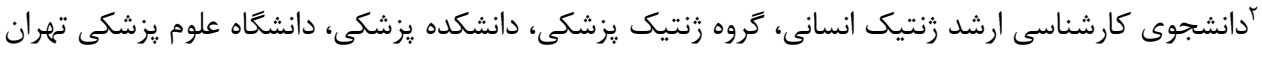

در اوايل سال r ا • r دنياى علم شاهد يك كشف جذاب به نام

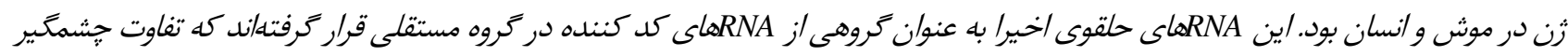

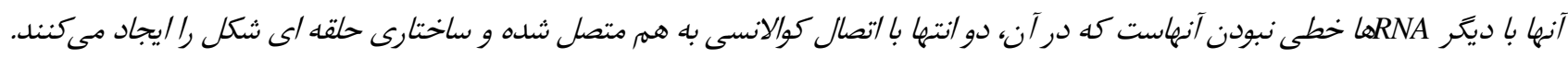

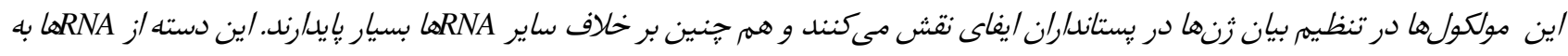

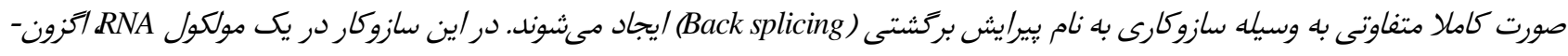

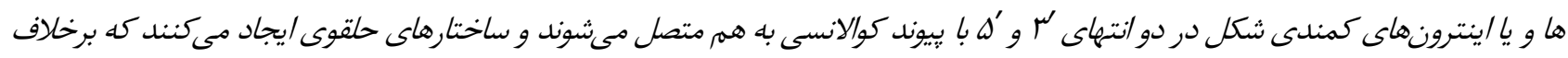

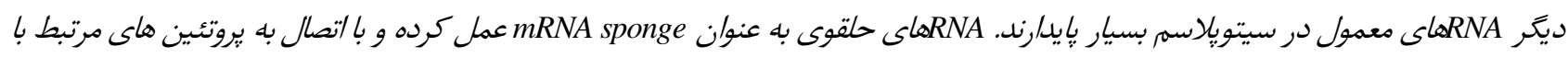

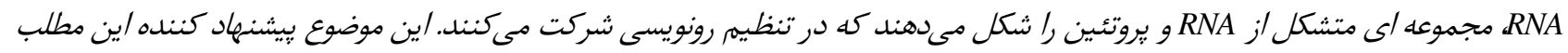

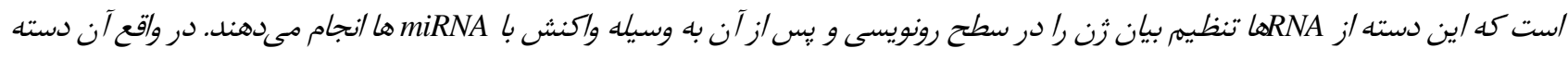

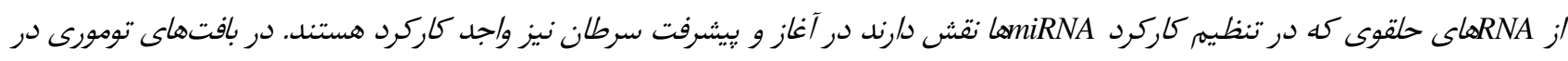

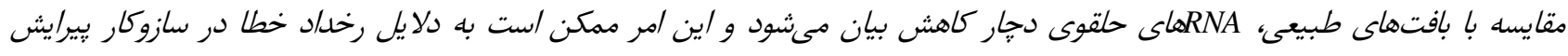

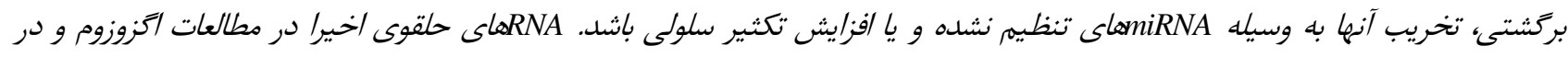

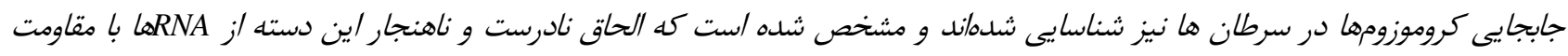

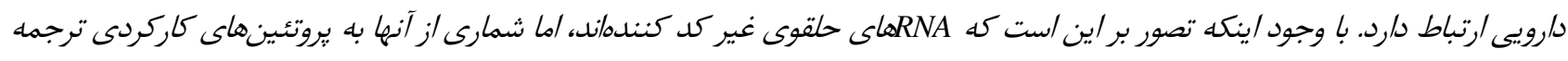

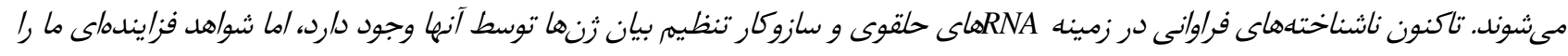

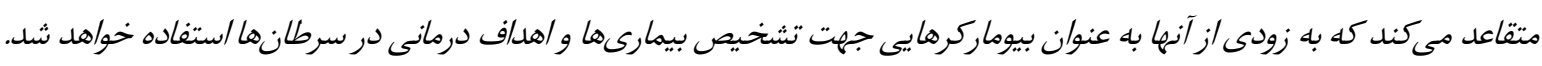

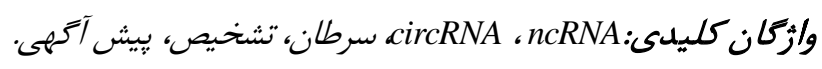

هاى حلقوى حاصل بيرايش برگشتى اتزونها، اينترونها

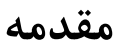

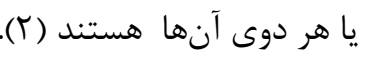

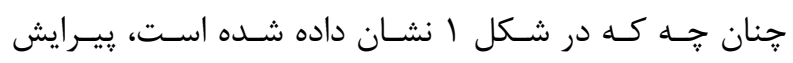

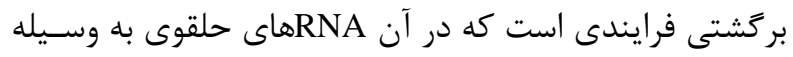

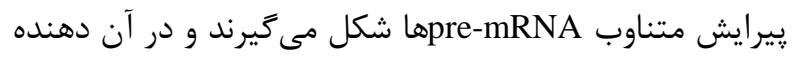

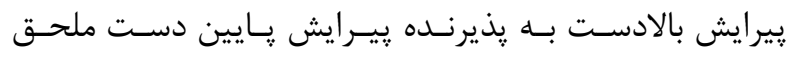

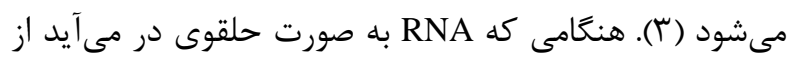

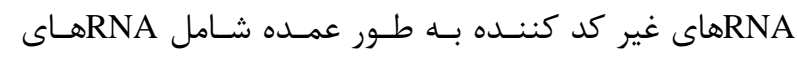

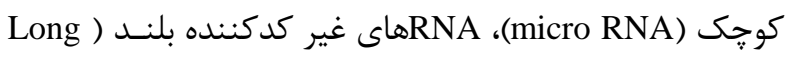

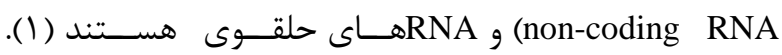

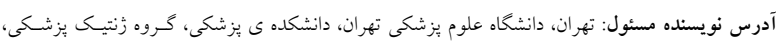
محمدرضا نورى دلوئى (email: nooridaloii@sina.tums.ac.ir) ORCID ID: 0000-0002-9044-9842 تاريخ دريافت مقاله: 9N/M/TV تاريخ هذيرش مقاله: 9M/T/4 


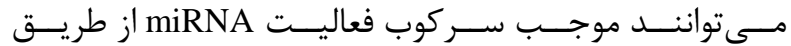
شوند؛ بنابراين افزايش يا كاهش بيان زن هدف sequestration

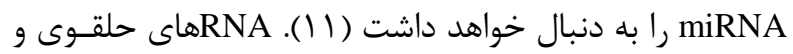

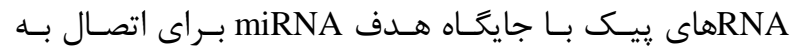

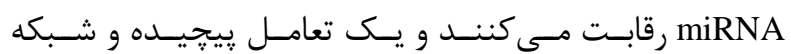

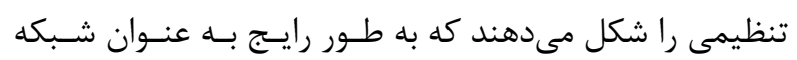

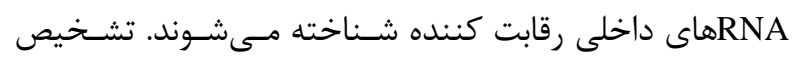
اهداف miRNA به مقدار زيادى به توالى مكمل بـين ناحيـهاي

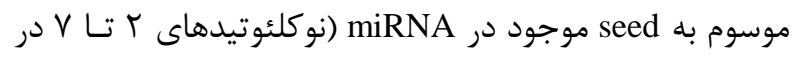

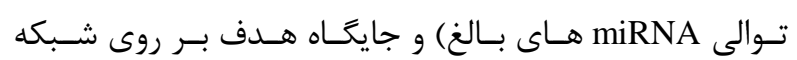

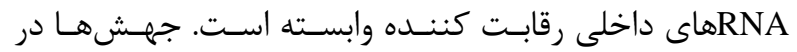
miRNA

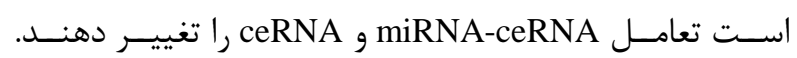
اختلال درتنظيم بـين شـبكههـاى RNAهـاى داخلـى رقابـت

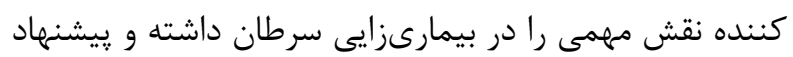

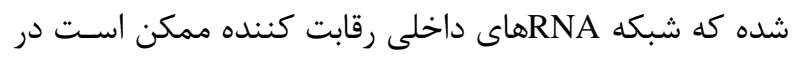

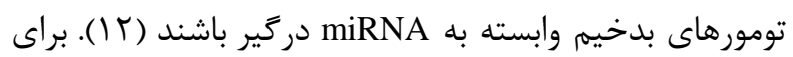

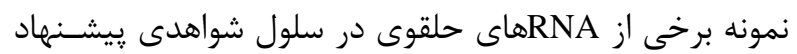
مى كنند كه اين RNA هما ممكن است رونويسى شده ورئ مسيرها

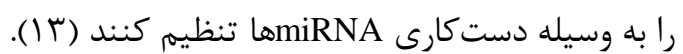
با اين حال برخى مطالعات نشان دادهاند كه كاركرد كلى يـى

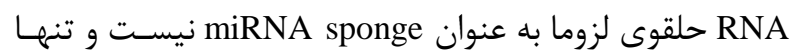
تعداد كمى از RNAهاى حلقوى واجد اين نقش هستند (F) به (I).
تخريب توسط اتزونوكلئازهـا مصـون مانـده و موجـب ثبـات و

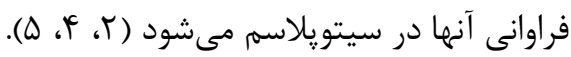

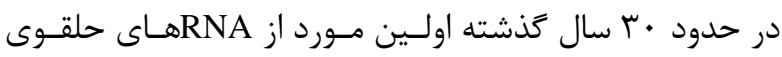

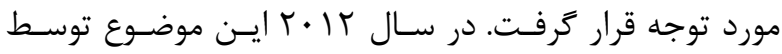
Salzman هاى حلقوى در رده سلولهاى سرطانى و غير سرطانى و

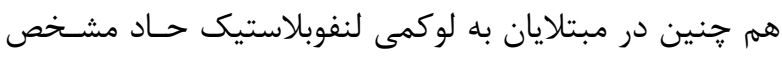

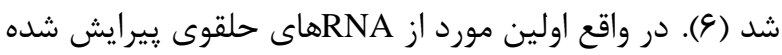
به دنبال آناليز زن حذف شده در سرطان كولوركتال( Deleted (in Colorectal Cancer or DCC يايه RT-PCR و توالى يابى كشف شـد (V). مطالعـه ديخـر بـر

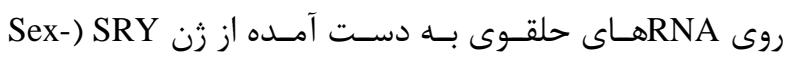

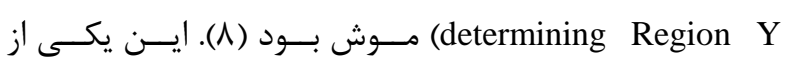
اصلى ترين RNAهاى حلقوى شناخته شده است كه به وسـيله

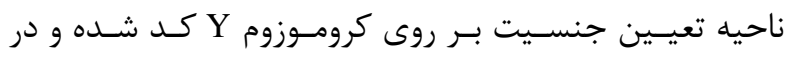

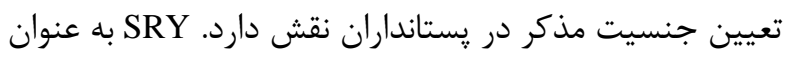

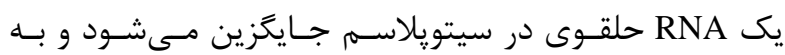

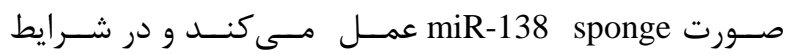

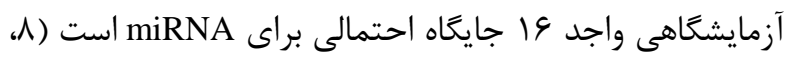
9.

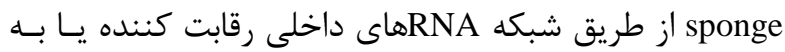
اختصـار competing endogenenous RNA) ceRNA) است

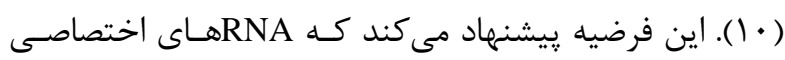

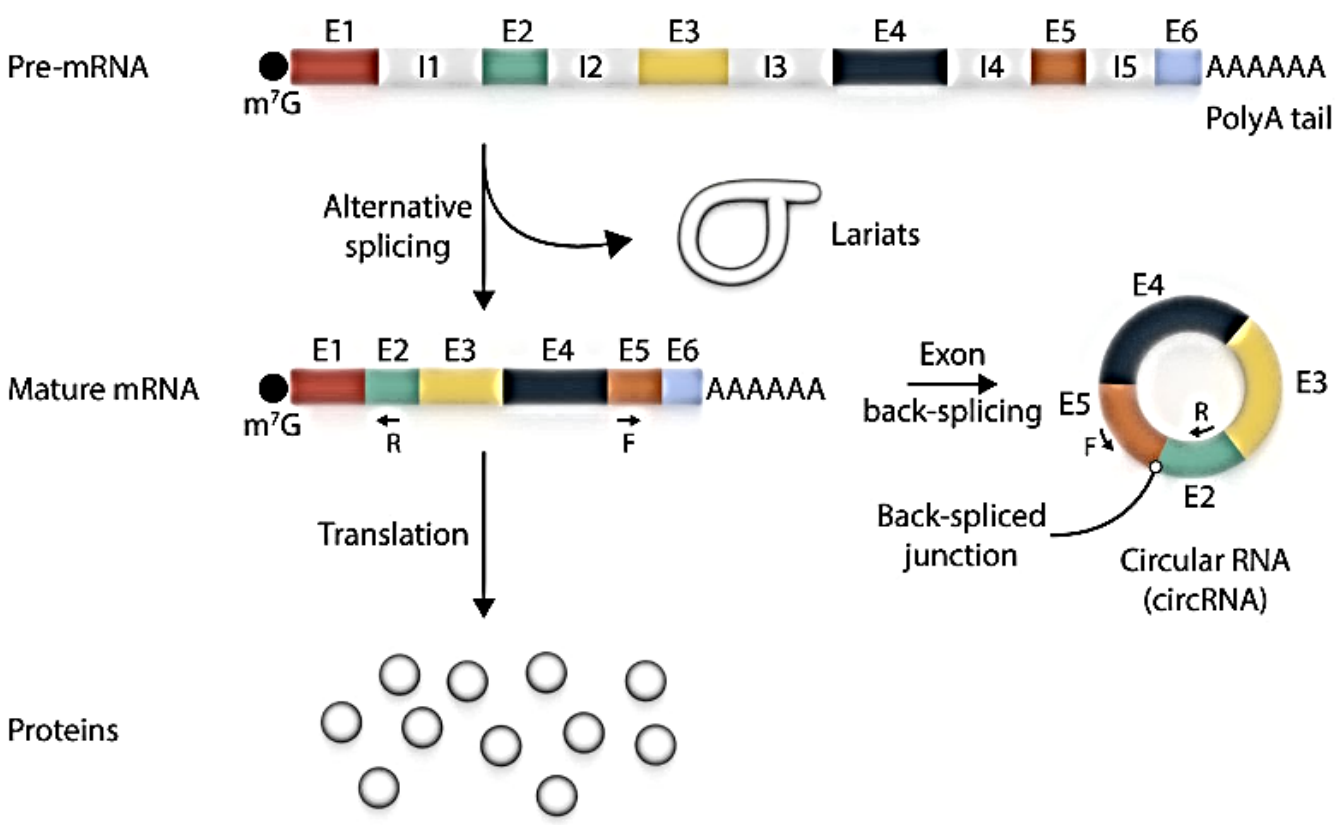

شكل ا. نمايش شماتيك از فرايند بِيرايش بركشتى كه منجر به ايجاد RNAهاى حلقوى مىشود. 
ساختارهاى انتهايى معمول (كلاهـك 'ها و دم ريلى A) بـوده و

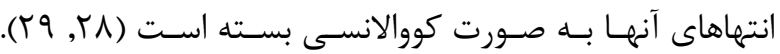

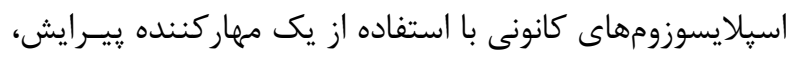

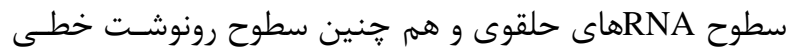
ييرايش شده را كاهش مى دهند. به بيان ديكر اسيلايسوزومهـا

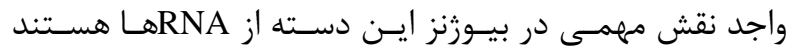
(• (ّ). لازم به تاكيد است كه بيان RNA هاى حلقوى هميشه بان

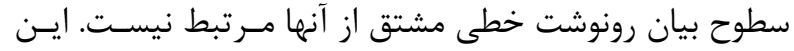

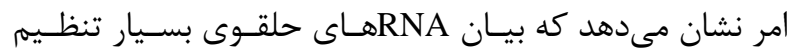

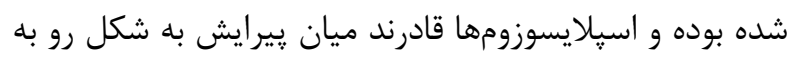

جلو و پيرايش برَشتى تمايز قائل شوند (Iآ). هاى حلقوى ممكن است از اكزونها و يا اينترونها ايجاد

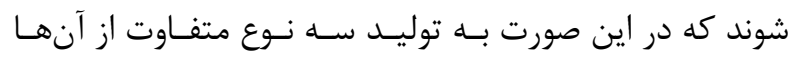

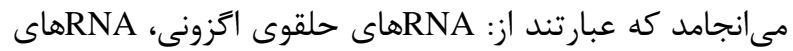

حلقوى اينترونى و RNA هاى حلقوى اكزونى -اينترونى (r).

\section{شناسايى و رديابى RNA}

از زمـان كشـف اولـين RNAهـاى حلقـوى تـاكنون ابزارهـاى

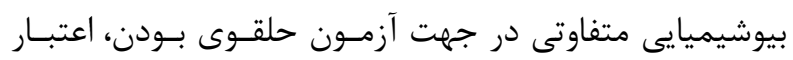
سنجى و شناسايى بيان نابجاى RNAهاى حلقوى ايجاد شـده

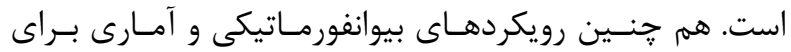

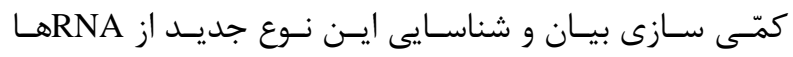

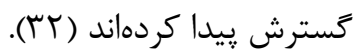
آزمونهـاى بيوشـيميايى ابـزار مهمسى جهـت اعتبارسـنجى و و

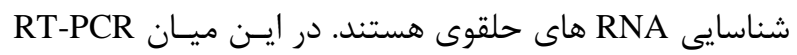

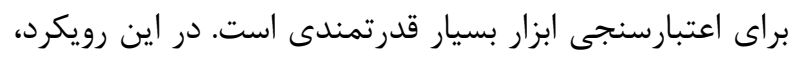

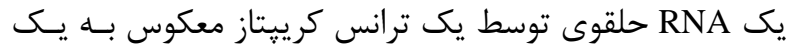

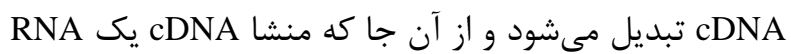

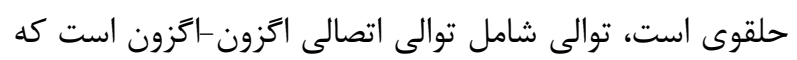

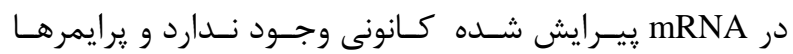
مىتوانند بـراى تكثيــر اختصاصى و شناسـيـى ايسن اتصـالات

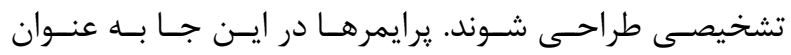

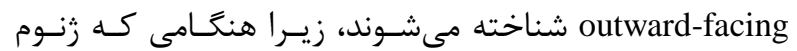
مىشود، انتهاهاى '3 به دور از همديخر قرار مى كيرند.

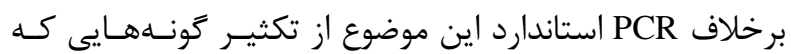

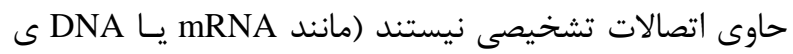

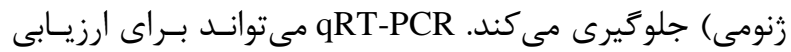

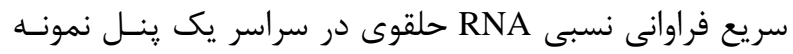
مورد استفاده قرار كيرد (سب).

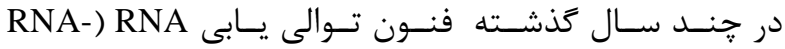

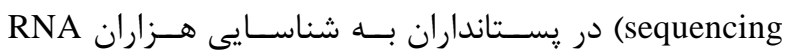

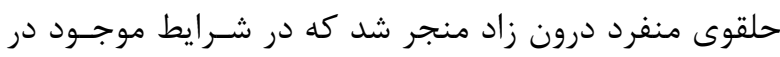

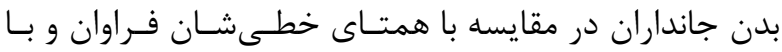

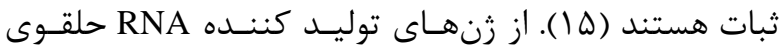

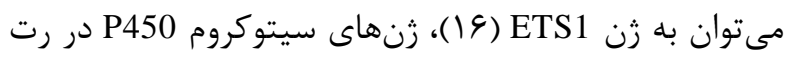

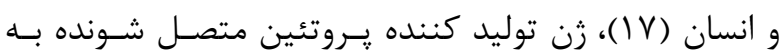

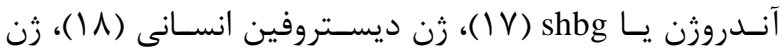
NCXI

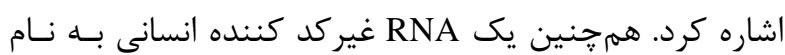
نيز يافت شده است كه تعداد كمى از رونوشتهـاى

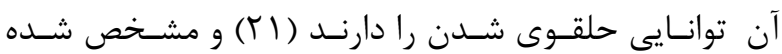

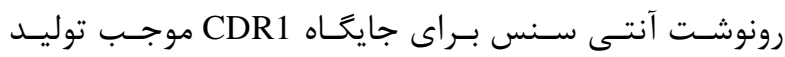

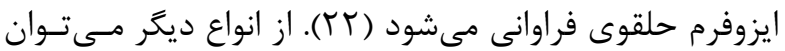

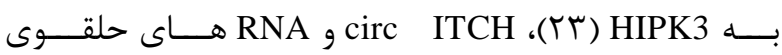

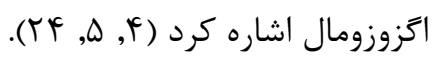

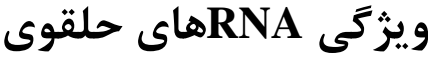

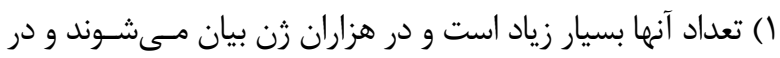
برخى موارد بيان بالاترى را نسبت به ايزوفرم خطى شناخته شـده

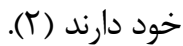

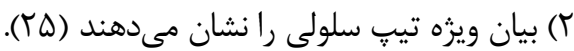
r) بين موش و انسان محافظت شدهاند (T). (1) در سيتويلاسم مستقرند (9).

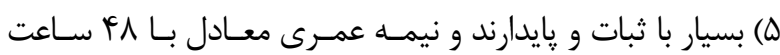
دارند (T). צ) به نظر نمىرسد كه RNA هاى حلقوى طبيعى ترجمـهـ شـوند، (1).

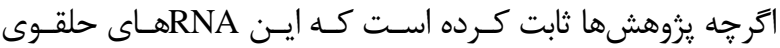

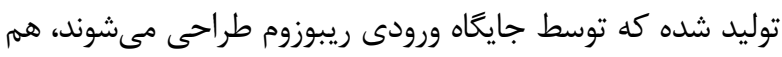

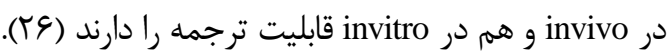

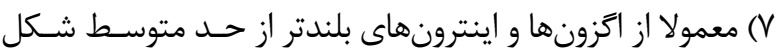

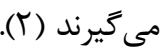
A)در خلال تكامل زيستى بيان يويايى دارند(Y) (YV).

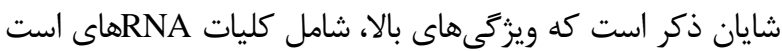

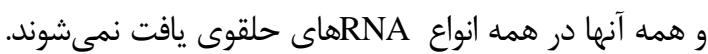

\section{توليد هاى حلقوى}

هاى حلقوى در خلال بيرايش بركشتى توليد مسىشـوند.

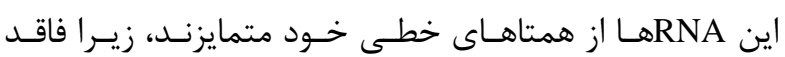


مرتبط با جرخه سلولى در سرطان يستان شناسـايى شـد. ايـن

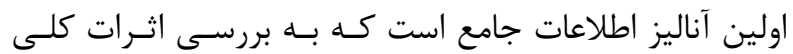

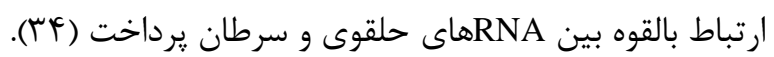

\section{كاركردهاى هاى حلقوى در سرطانها}

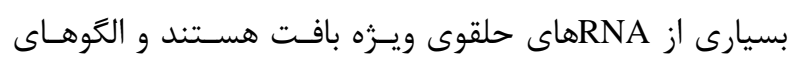

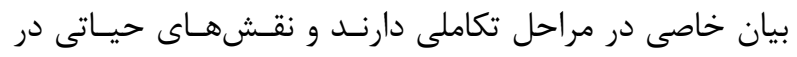
فرايندهاى زيست شناختى مرتبط با سرطان بـازى مسى كنــــــ

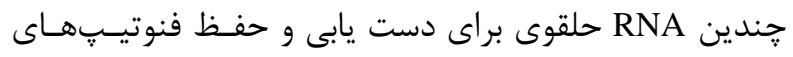

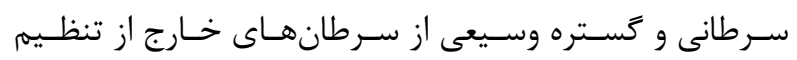
ضرورى هستند. يزوهشهاى اخير به اين نتيجه رسيدهاند كـهـ

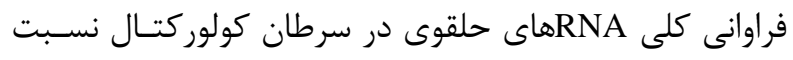

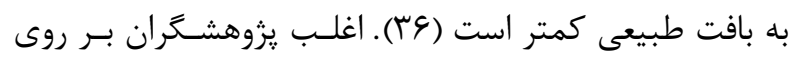

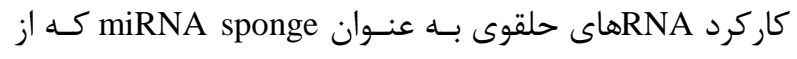

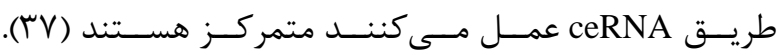

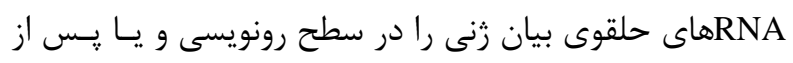

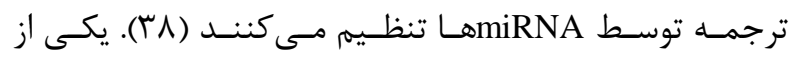
بيشـترين مطالعـات در زمينـهـ miRNA و شــبكه ceRNA بـا

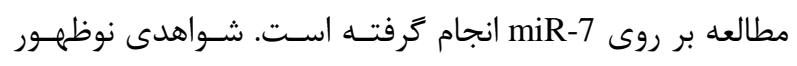

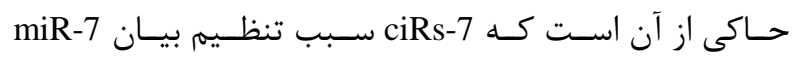
مىشود. miR-7 به طور مستقيم مى تواند موجب كـاهش بيـان انكوزنهايى مانند كيرنده عامـل رشـد إيــدرمى ( Epidermal p21 Growth Factor Receptor

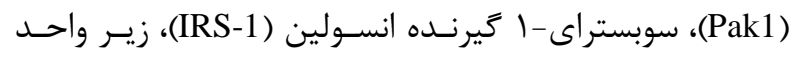

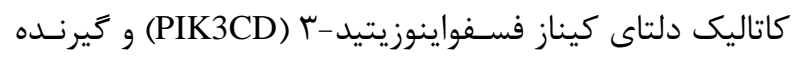

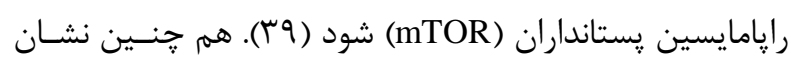

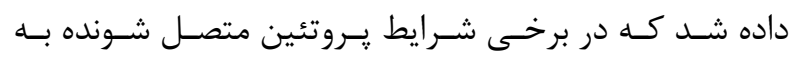

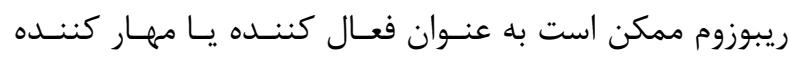
تنظيمى در شكل كيرى RNAهاى حلقوى عمـل كنــــ (YY)

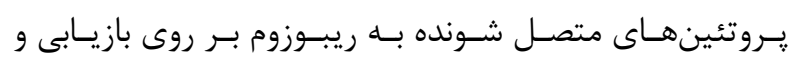

به منظور سازمان دهى فعـال RNAهـاى حلقـوى يايخـاههـاى

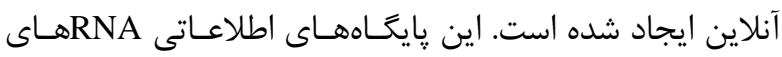
حلقوى را از Gene bank يا مقالات منتشـر شـده جمـع آورى إنى

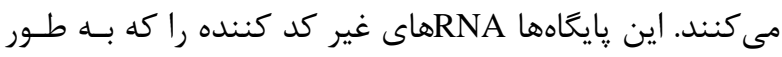
تجربسى تاييـد شـدهانـد، RNAهـايى كـهـ صـرفا يـيش بينـى

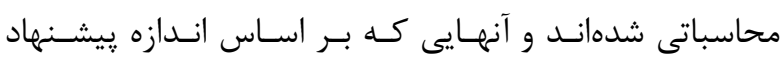

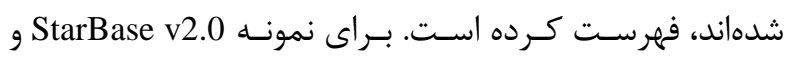

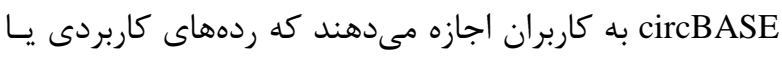
فرايندها را جستجو كنند. circ2Traits و nc2 cancer به كاربر اجازه مى دهد براساس بيمارى (مانند سرطان) جسـتجو انجـام

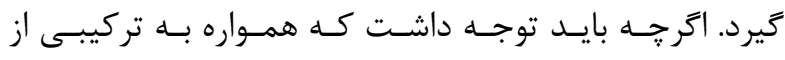

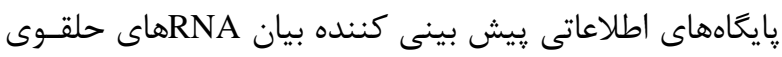
و يايگاههاى اطلاعاتى ديخر كه بر مبناى بيمارى هستند (مانند بيند (Circ2 Traits db/؛ http://gvanxet-beta com/circ

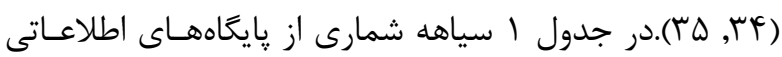
مرتبط با RNAهاى حلقوى آورده شده است.

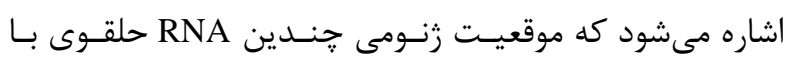

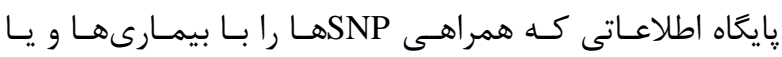
بيمارىهاى مرتبط با نواحى زنتيكى خاص را اعلام مسى كنـــد،

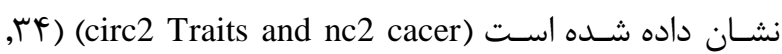

Ghosal و همكارانش احتمال همراهى بيمـارى بـا يـك RNA

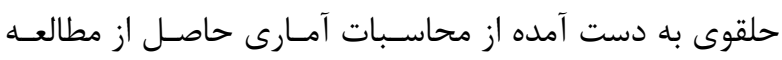
تعامل بين RNAهاى حلقوى و microRNA مرتبط با بيمـارى

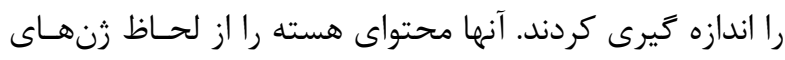
كد كننده يروتئين در بيمارىهايى كـهـ بـين MiRNA و RNA

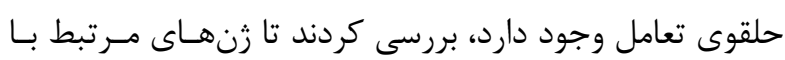
فرايندهاى زيست شناختى ويره را شناسايى كنند. فراينـدهاى

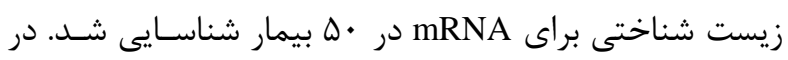

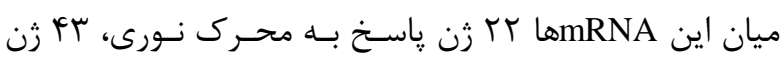

جدول ا. سياهه مربوط به تعدادى از يايخاه هاى اطلاعاتى كاربردى مرتبط با RNA هاى حلقوى

\begin{tabular}{ll}
\hline Name of database & Functions \\
\hline CircRNA & The sequence and expression information \\
circRNADb & Protein-encoding feature annotation \\
Circ2Traits & MiRNA-circRNA-mRNA-lncRNAs intraction network for diseases. \\
Deepbase & Comprehensive annotation of sRNAs.lncRNAs and circRNAs \\
circInteractome & Circular RNAs and their interactions with other binding factors (RBPs and miRNA) \\
circNET & Tissue-specific circRNA expression profile.circRNA/mRNA/gene regulatory \\
& networks \\
starBase & Systematically identify the RNA-RNA and protein-RNA interaction networks \\
CIRCexploret2 & Annotate alternative back-splicing and alternative splicing in circRNAs \\
\hline
\end{tabular}


هاى دركير در EMTRA فراهم كند (צץ). علاوه بر اينها

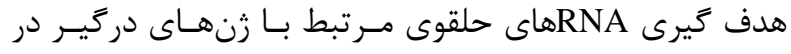

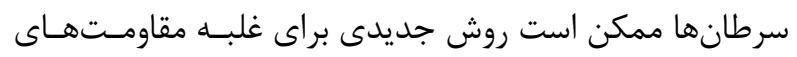

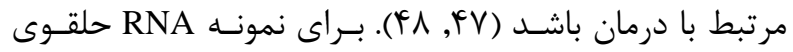
(circ HIAT1) HIAT1

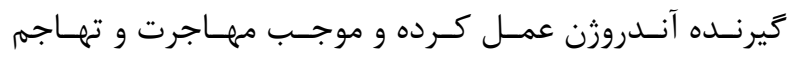

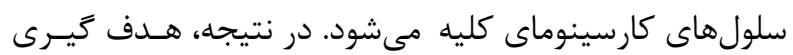

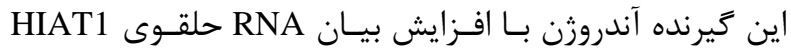

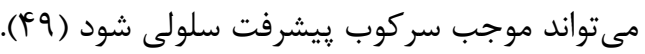

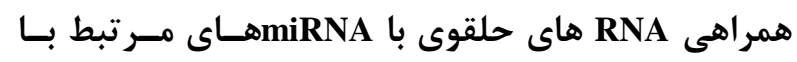
سرطان

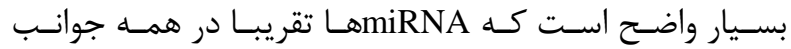

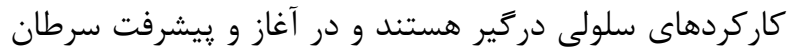

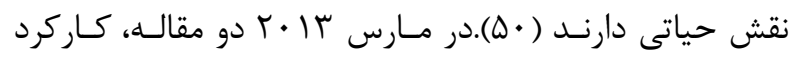

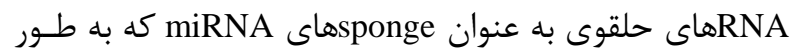

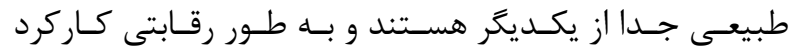

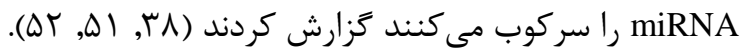

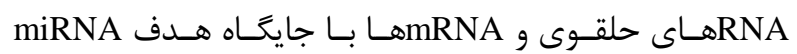
معمولى براى اتصال به miRNA رقابت مى كنند و يـك تعامـل

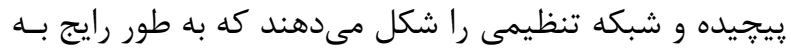

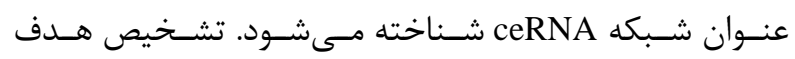

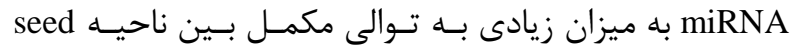

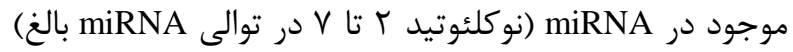

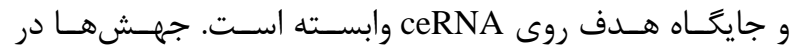
miRNA (به ويزه در ناحيه ى seed) و جايخـاهــاى هدفشـان

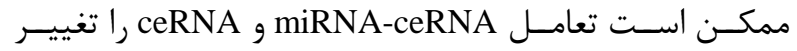
دهند (r) (I). اختلال عدم تنظيم بين در شبكه نقش مهمى را در بيمارىزايى سرطان دارد. يِيشنهاد شده اسـت كـهـ

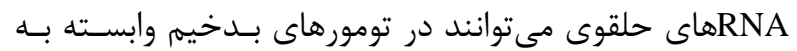

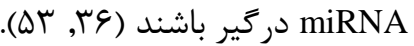

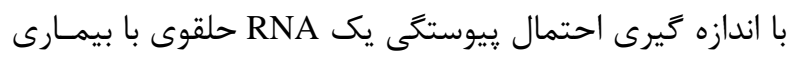

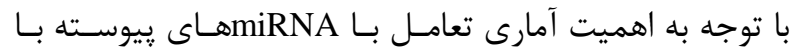

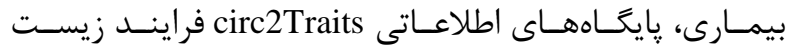

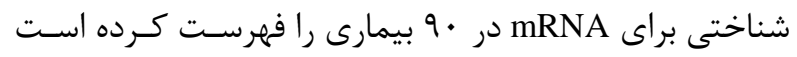

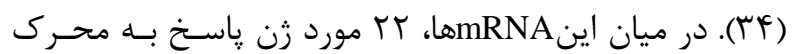

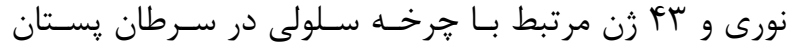

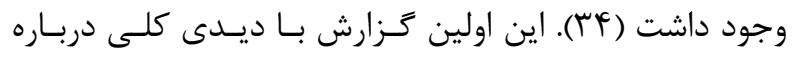

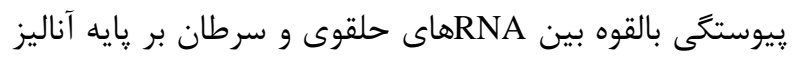

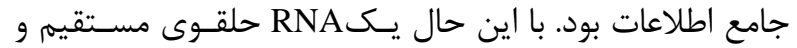
هiRNA همراه براى شواهد زيست شناختى بيشتر مـورد نيـاز
رونويسى mRNA ها اثر زذاشـته و در تعـدادى از بيمـارىهـا

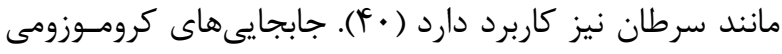

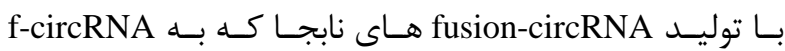
شهرت دارند، در سرطانها نقش دارند ( أf). در واقع با الحساق

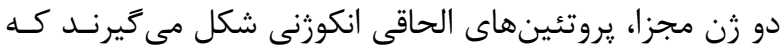

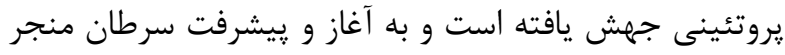

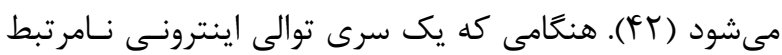

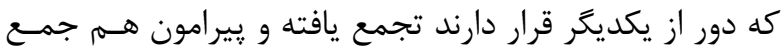

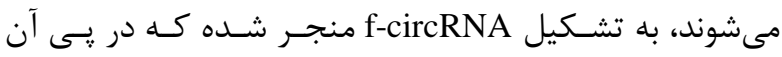
ييرايشهاى بركشتى جديدى رخ مى رهد (سا).

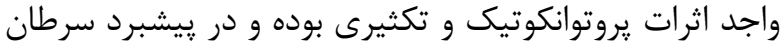
با تحريك فعاليت مسيرهاى انتقـال سـيكنال PI3K و

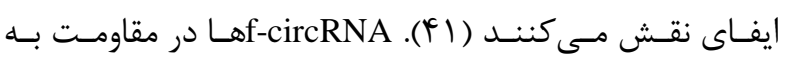
درمان نيز نقش دارند. براى نمونه، f-circRNA سبب مقاومـت درت

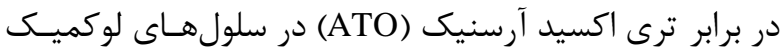

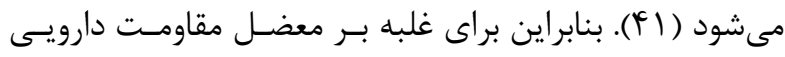
هدف كيرى RمNA هاى حلقـوى ممكـن

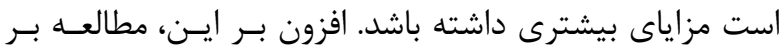

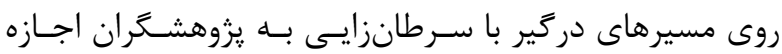

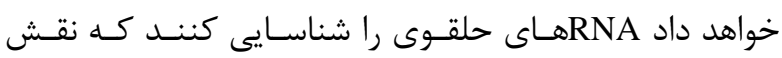
بيوماركرى دارند؛ براى نمونه برخى از انواع هاع ماى حلقـوى

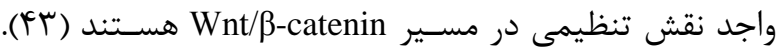

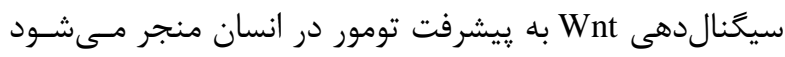

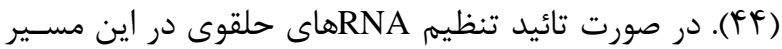

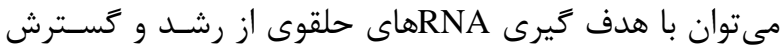

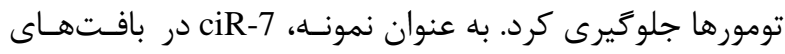
سرطانى موجب مهار miR-7 و در بيى آن فعال شدن انكوزنهاى ندئ

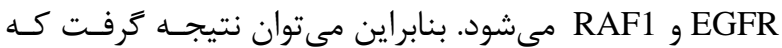

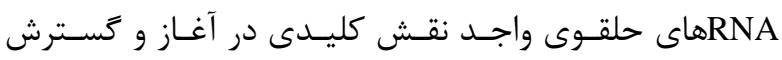

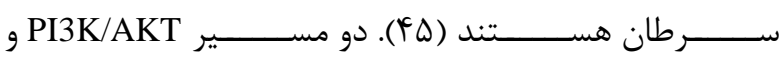

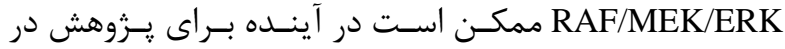
زمينه تنظيم بالقوه RNAهاى حلقوى مورد مطالعه قرار گيرند

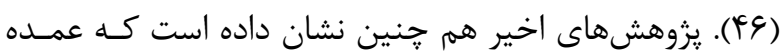

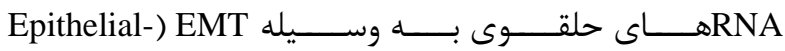
Mesenchymal Transition

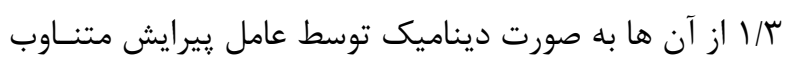
كه به وسيله فرايند EMT تنظيم شدهانـد، تنظـيم مسىشـوند. شركت EMT در تومورزايى نشانههاى مهمى را براى ييشـرفت

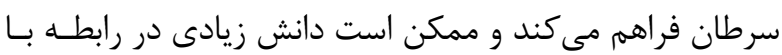

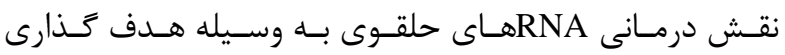


حلقوى در كارسينوماى سـلولهـاى كبـدى بــرخلاف بافتهـاى

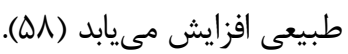
سرطان كولوركتال سرطان كولوركتال به عنوان سومين سرطان رايج و سـومين علـت

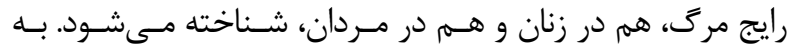

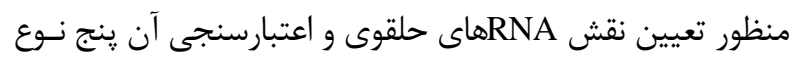

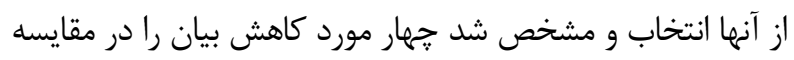

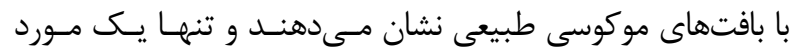

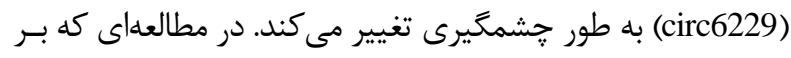

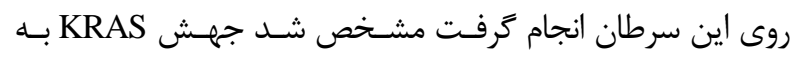

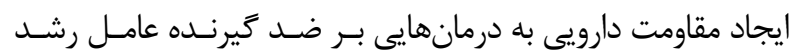

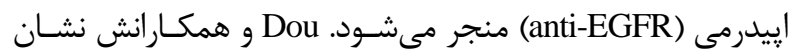

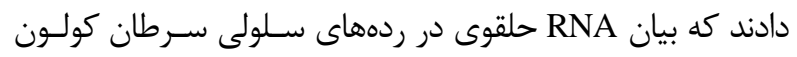

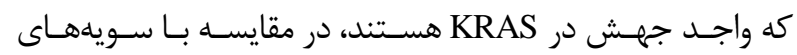

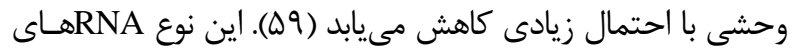

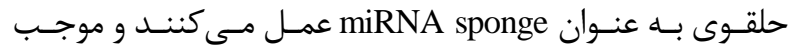

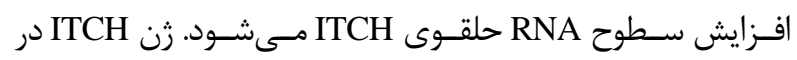
مسير Wnt/Bcatenin دركيــر اسـت و موجـب شـروع و يِيشـرفت سرطان كولوركتال مىشود (•) س. (؟). سرطان معده سرطان معده در بسيارى از ملل توسعه يافته با وجود كاهش قابـل توجه در بروز، اغلب به عنوان يكى از علل رايج مرك دهاى ناشى از از

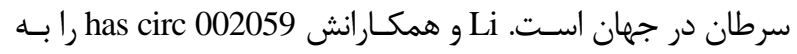

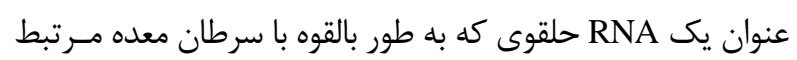
است، شناسايى كردنـد ( (9).

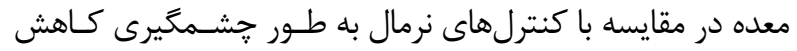

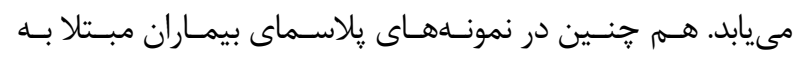

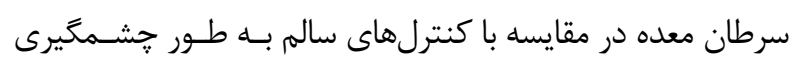
كاهش مى يابد و با ويزَكى هاى بافت شناسى و بالينى مانند مر حلـه،

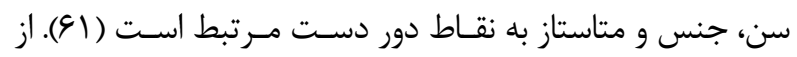

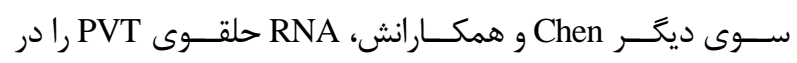
بافتهاى تومورى معده شناسايى كردند و مشخص شد كه در ايـن

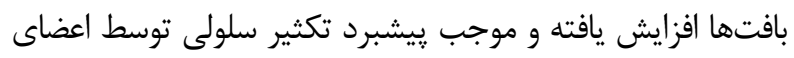
خانواده miR-125 مىشود (GT). سرطان مثانه سرطان مثانه از يوشش إيدرمى مجارى ادرارى ناشى مىشـود

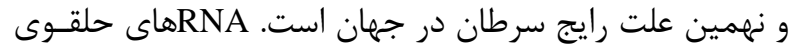

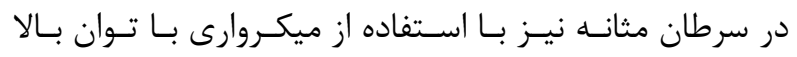

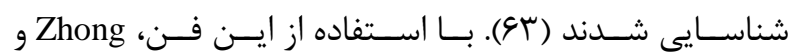

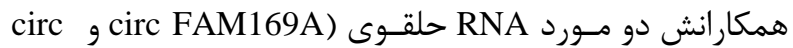

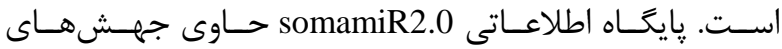

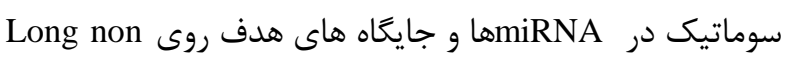
هاى حلقوى و هiRNA، coding RNA

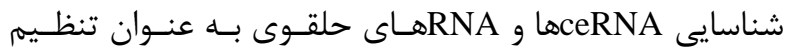

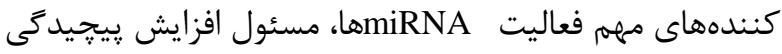
هاى غير كد كننده ميانجى شبكههاى تنظيمى هسـتند.

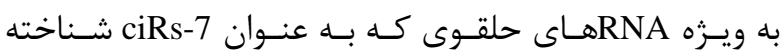

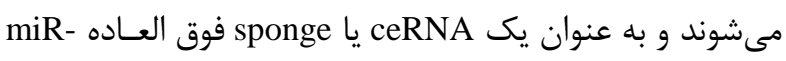

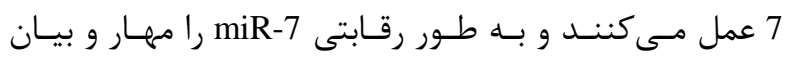

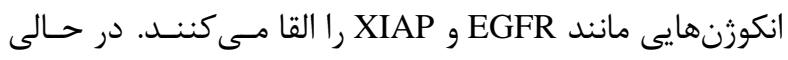

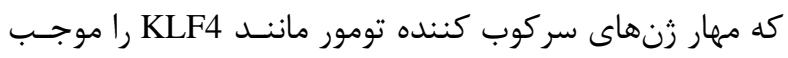

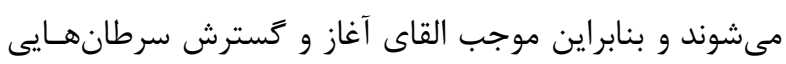

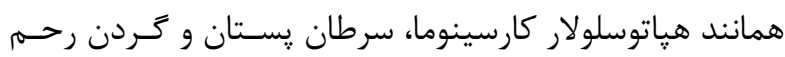

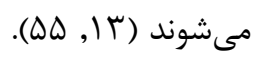
شناسايى تنظيم محور فعاليت miR-7/miR-67/ciR-7 احتمالا

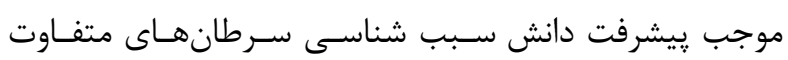

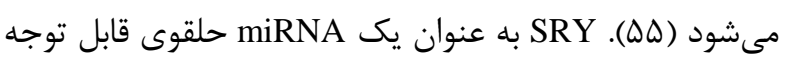

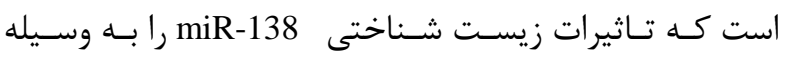

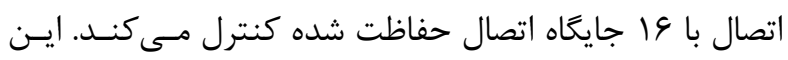

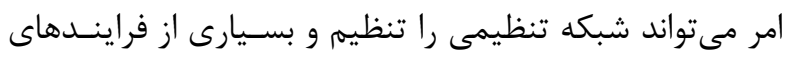

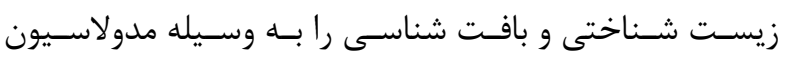

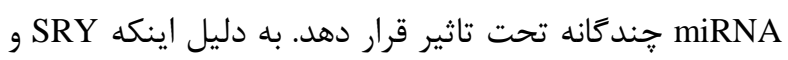

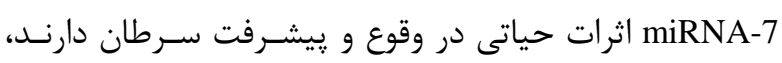

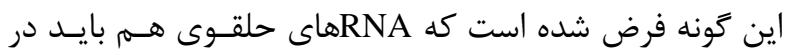
اين فرايند دخيل باشند (YN).

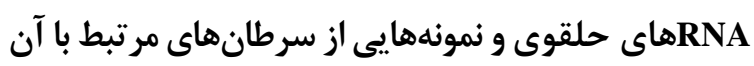

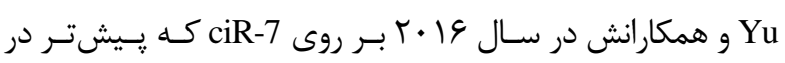

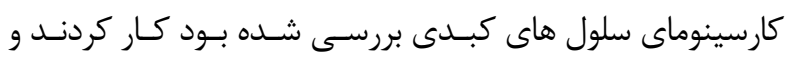

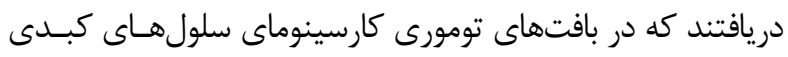

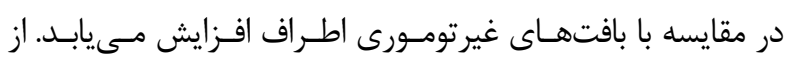

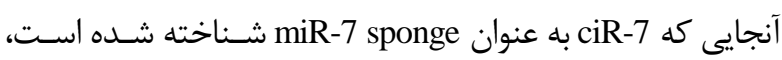

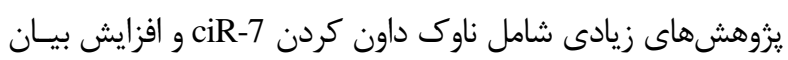

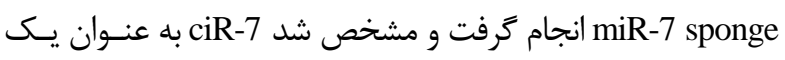

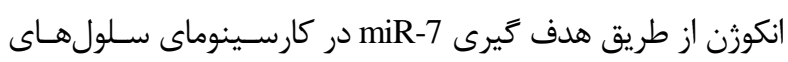

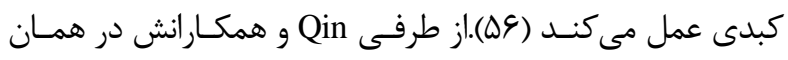
سال نوعى RNA حلقوى به نـام

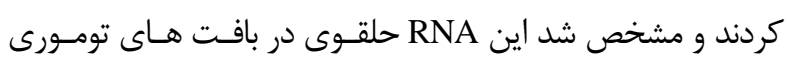

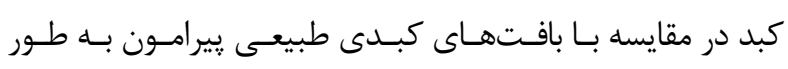

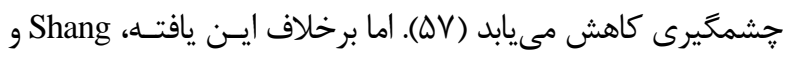

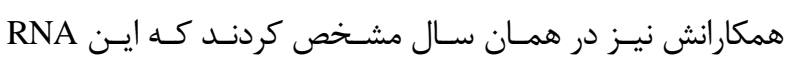


دارد. ييش بينى شده است كـه اثـرات ييـرايش CANRIL بـــ ســركوب INK4/ARF منجــر شـده و موجــب افـزايش خطــر آترواسكلروزيس مىشود ( (Y). هييوكسى عامل خطر شـناخته

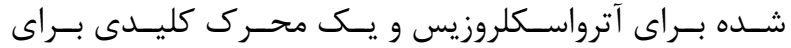
آنزيوزنزيس است كه توسط RNAهاى حلقوى تنظيم مىشـود

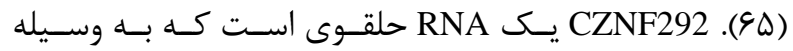

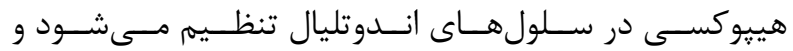

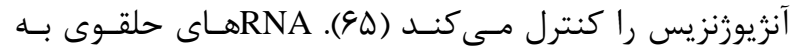

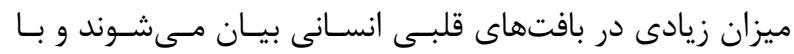

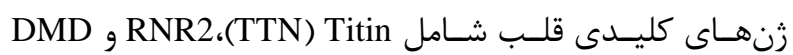
ارتباط دارنـد (99). شـواهد بيشـترى بــراى نقـش مهــRNA حلقـوى در بيمـارىهـاى قلبـى -عروقىى بـهـ وسـيله Jakobi

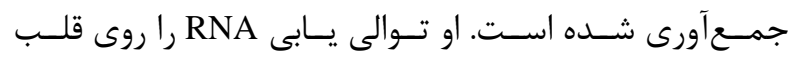
موشهاى بالغ انجام داد و بيش از DVD مورد RNA حلقـوى را كه نامزد بيمارى قلبى هستند شناسـايى كـرد (SV). برخسى از

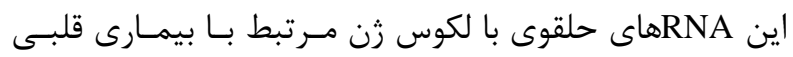

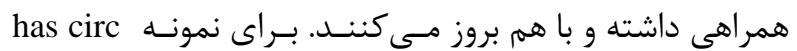

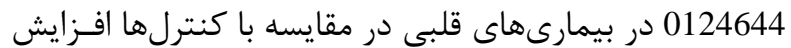

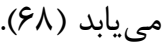
ديابت ديابت نوعى بيمارى مزمن است كه منجر به ايجاد ناهنجارىهـاى

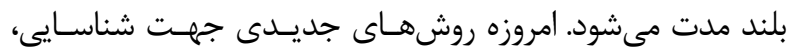
تشـخيص و درمـان بهتــر مـورد نيـاز اسـت. افـزايش miR-7 در

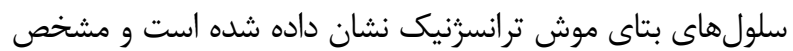

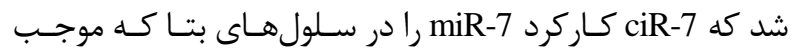
ترشح انسولين مى شود را بهبود مىبخشد (99).

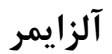
مطالعات اوليه نشان دادهاند كه RNAهاى حلقـوى بــه ميـزان زيادى در مغز بيان مىشـوند (ب/) و ممكـن اسـت در تنظـيم

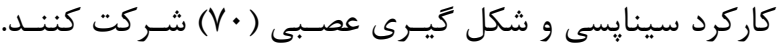

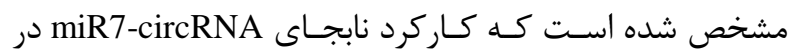
ناحيـه CA1 هيبيو كامسب مغــز در آلزايمــر اسـيوراديك ايجــاد

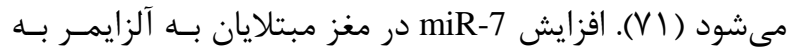

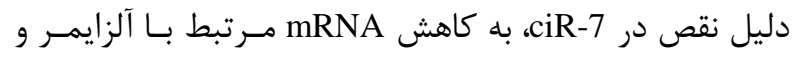

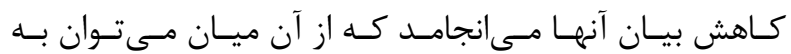
UBE2A اشـاره كـرد (UBE2A) ubiquitin conjugase در جرخه يوبى كوئيتيناسيون بـه عنـوان يـك افكتـور مركـزى

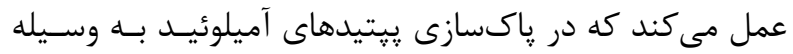
فاگوسيتوز درگير است. در مغز مبتلايان به آلزايمر اسيوراديك

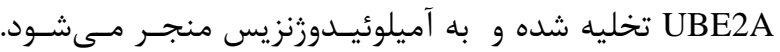

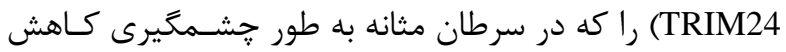
مىيابند، شناسايى كردند (س).

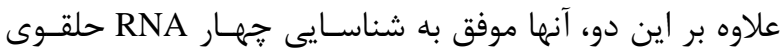

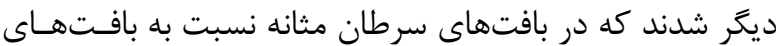
غير تومورى ييرامون به طور جشمگيرى افزايش مىيابند (circ RNA .circ BCO48201 و circ PTK2،circ ZFR،TCF25 حلقوى TCF25 به عنوان miRNA sponge عمل مي كند و در بافتهاى سرطانى موجب كـاهش miR-103a-3p و miR-107

و افزايش CDK6 و سرانجام گسترش سرطان مىشود (سأ). كارسينوماى سلول هاى كبدى كارسينوماى سلولهاى كبدى يك بدخيمى مربوط به كبـد اسـت و به طور غالب در مبتلايـان بـه بيمـارى كبـدى مـزمن و ســيروز كبدى رخ مىدهد.در اين بيمارى RNAهـاى حلقـوى در مقايسـهـ

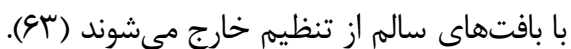
Q و همكارانش has-circ-0001649 را در اين بيمارى شناسـايى كردند و متوجه شدند كه در بافتهاى تومورى در مقايسه با بافت

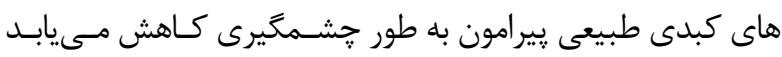

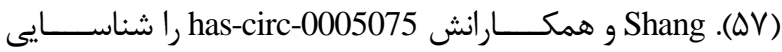
كردند و متوجه شدند كـهـ در بافتهــاى تومـورى در مقايســه بـا

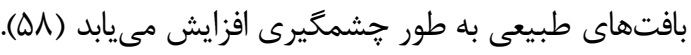
Yu

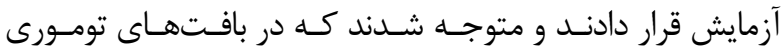
كارسينوماى سلولهاى كبدى در مقايسه با بافتهاى غيرتومـورى

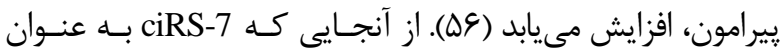

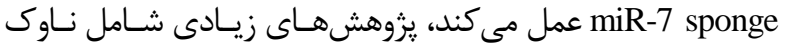

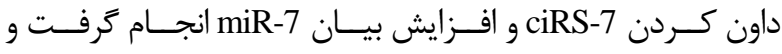

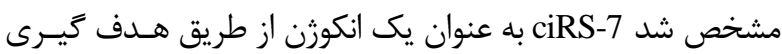

miR-7 در كاسينوماى سلولهاى كبدى عمل مى كند (\$) (\$).

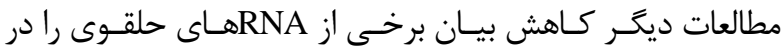

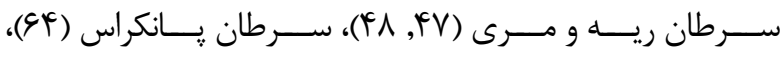

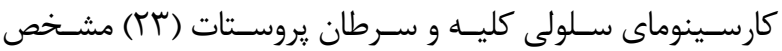
كردند.

\section{نمونههايى از ديگر بيمــارىهــاى مــرتبط بــا هاى حلقوى RNA بيمارى قلبى ايسكميك} اين بيمارى علت ييشروى مرى در كشـورهاى توسـعه يافتـهـ است. CANRIL يكى از نخستين RANAهاى حلقـوى شـناخته شده است كه با جندشكلى هاى تك نوكلئوتيدى رايج همراهى 


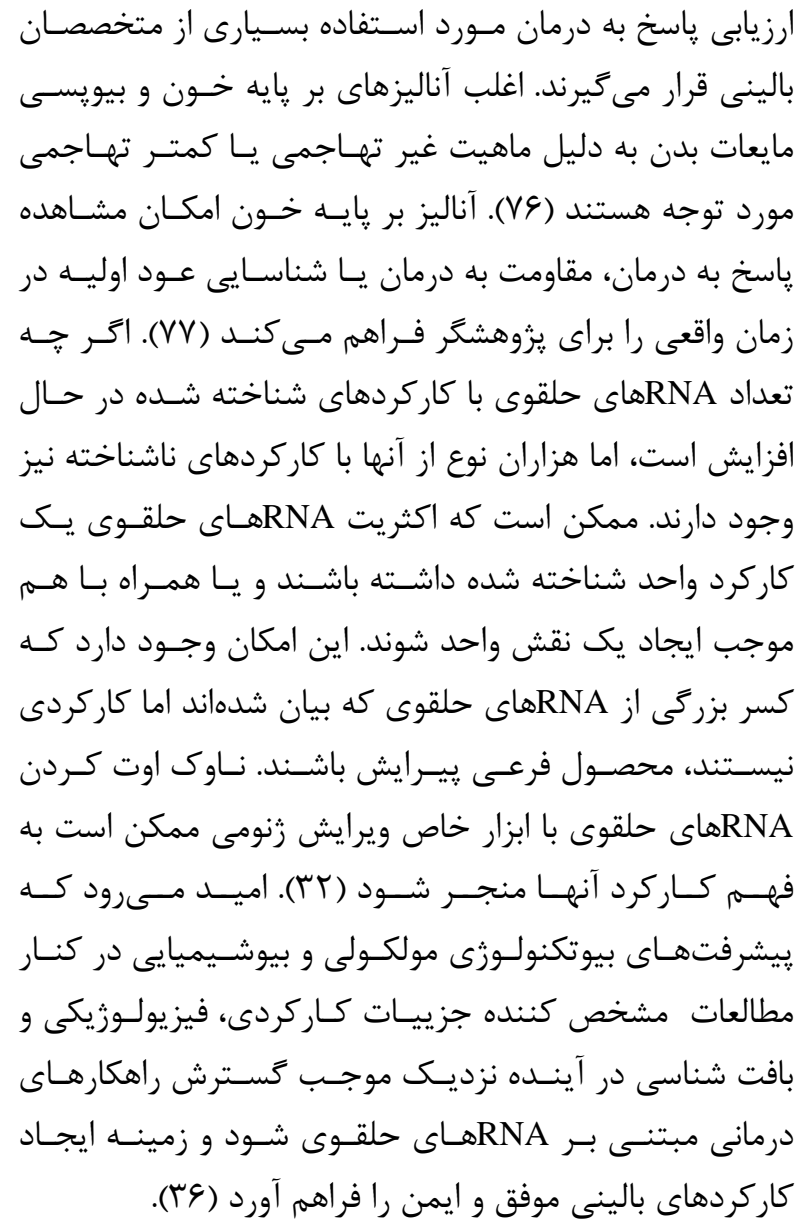

شواهد بيشتر براى يك ارتباط با پيرى از شناسايى RـNAهاى

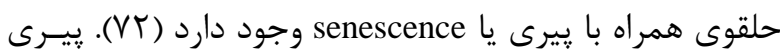
وضعيتى است كه در بى مواجهه سلولها با محرك هـاى ايجـاد

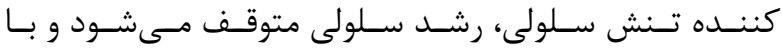
فرايندهايى مانند sarcopenia، آرتريت، ديابت، تخريب عصدبى سنى و سرطان مرتبط است (T).

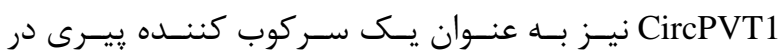
فيبروبلاستهاى تكثير كننده عمل مى كند (VQ, V (VQ).

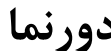

يزولهشهاى وسيعى موجب تعميق فهم مـا از شـبكه يِيجيـده

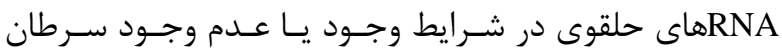

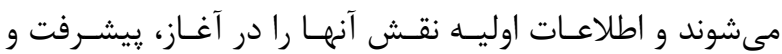

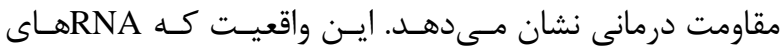

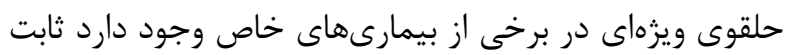

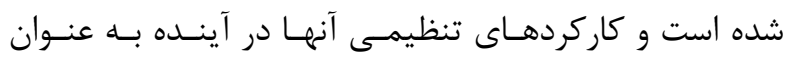

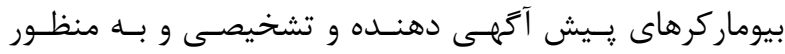

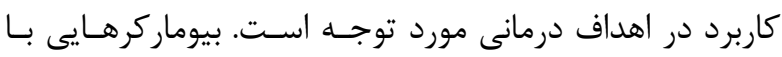

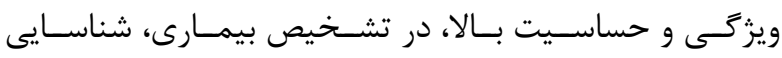
جمعيت در معرض خطر بالا، كسترش درمـانهـاى هدفمنـد و

\section{REFERENCES}

1. Warner JR. The economics of ribosome biosynthesis in yeast. Trend Biochem Sci 1999;24:437-40.

2. Jeck WR, Sorrentino JA, Wang K, Slevin MK, Burd CE, Liu J, et al. Circular RNAs are abundant, conserved, and associated with ALU repeats. RNA 2013;19:141-57.

3. Barrett SP, Wang PL, Salzman J. Circular RNA biogenesis can proceed through an exon-containing lariat precursor. Elife 2015;4:e07540.

4. Noori-Daloii M. Medical molecular genetics in the third millennium. Tehran, Iran: Samer Publication; 2012. [In Persian]

5. Noori-Daloii M, ed. Emery's elements of medical genetics.8th ed. Tehran, Iran: Jame-negar and Salemi Publication; 2017. [In Persian]

6. Salzman J, Gawad C, Wang PL, Lacayo N, Brown PO. Circular RNAs are the predominant transcript isoform from hundreds of human genes in diverse cell types. PloS One 2012;7:e30733.

7. Nigro JM, Cho KR, Fearon ER, Kern SE, Ruppert JM, Oliner JD, et al. Scrambled exons. Cell 1991;64:607-13.

8. Capel B, Swain A, Nicolis S, Hacker A, Walter M, Koopman P, et al. Circular transcripts of the testis-determining gene Sry in adult mouse testis. Cell 1993;73:1019-30.

9. Koopman P, Münsterberg A, Capel B, Vivian N, Lovell-Badge R. Expression of a candidate sex-determining gene during mouse testis differentiation. Nature 1990;348:450.

10. Taulli R, Loretelli C, Pandolfi PP. From pseudo-ceRNAs to circ-ceRNAs: a tale of cross-talk and competition. Nat Struct Mol Biol 2013;20:541.

11. Thomson DW, Dinger ME. Endogenous microRNA sponges: evidence and controversy. Nat Rev Genet 2016;17:272.

12. Xiao-Jie L, Ai-Mei G, Li-Juan J, Jiang X. Pseudogene in cancer: real functions and promising signature. J Med Genet 2015;52:17-24.

13. Hansen TB, Kjems J, Damgaard CK. Circular RNA and miR-7 in cancer. Cancer Res 2013;73:5609-12. 
14. Salzman J. Circular RNA expression: its potential regulation and function. Trends Genet 2016;32:309-16.

15. Jeck WR, Sharpless NE. Detecting and characterizing circular RNAs. Nat Biotech 2014;32:453.

16. Cocquerelle C, Mascrez B, Hetuin D, Bailleul B. Mis-splicing yields circular RNA molecules. FASEB J 1993;7:155-60.

17. Zaphiropoulos PG. Exon skipping and circular RNA formation in transcripts of the human cytochrome P-450 2C18 gene in epidermis and of the rat androgen binding protein gene in testis. Mol Cell Biol 1997;17:2985-93.

18. Surono A, Takeshima Y, Wibawa T, Ikezawa M, Nonaka I, Matsuo M. Circular dystrophin RNAs consisting of exons that were skipped by alternative splicing. Hum Mol Genet 1999;8:493-500.

19. Li X-F, Lytton J. A circularized sodium-calcium exchanger exon 2 transcript. J Biol Chem 1999;274:8153-60.

20. Houseley JM, Garcia-Casado Z, Pascual M, Paricio N, O'dell KM, Monckton DG, et al. Noncanonical RNAs from transcripts of the Drosophila muscleblind gene. J Hered 2006;97:253-60.

21. Burd CE, Jeck WR, Liu Y, Sanoff HK, Wang Z, Sharpless NE. Expression of linear and novel circular forms of an INK4/ARF-associated non-coding RNA correlates with atherosclerosis risk. PLoS Genet 2010;6:e1001233.

22. Hansen TB, Wiklund ED, Bramsen JB, Villadsen SB, Statham AL, Clark SJ, et al. miRNA silencing involving Ago2

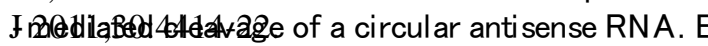

23. Zheng Q, Bao C, Guo W, Li S, Chen J, Chen B, et al. Circular RNA profiling reveals an abundant circHIPK3 that regulates cell growth by sponging multiple miRNAs. Nat Commun 2016;7:11215.

24. Conn SJ, Pillman KA, Toubia J, Conn VM, Salmanidis M, Phillips CA, et al. The RNA binding protein quaking regulates formation of circRNAs. Cell 2015;160:1125-34.

25. Salzman J, Chen RE, Olsen MN, Wang PL, Brown PO. Cell-type specific features of circular RNA expression. PLoS Genet 2013;9:e1003777.

26. Chen C-y, Sarnow P. Initiation of protein synthesis by the eukaryotic translational apparatus on circular RNAs. Science 1995;268:415-7.

27. Szabo L, Morey R, Palpant NJ, Wang PL, Afari N, Jiang C, et al. Statistically based splicing detection reveals neural enrichment and tissue-specific induction of circular RNA during human fetal development. Genome Biol 2015;16:126.

28. Vicens Q, Westhof E. Biogenesis of circular RNAs. Cell 2014;159:13-4.

29. Memczak S, Jens M, Elefsinioti A, Torti F, Krueger J, Rybak A, et al. Circular RNAs are a large class of animal RNAs with regulatory potency. Nature 2013;495:333.

30. Starke S, Jost I, Rossbach O, Schneider T, Schreiner S, Hung L-H, et al. Exon circularization requires canonical splice signals. Cell Rep 2015;10:103-11.

31. Chen L-L, Yang L. Regulation of circRNA biogenesis. RNA Biol 2015;12:381-8.

32. Barrett SP, Salzman J. Circular RNAs: analysis, expression and potential functions. Development 2016;143:183847.

33. Cocquet J, Chong A, Zhang G, Veitia RA. Reverse transcriptase template switching and false alternative transcripts. Genomics 2006;88:127-31.

34. Ghosal S, Das S, Sen R, Basak P, Chakrabarti J. Circ2Traits: a comprehensive database for circular RNA potentially associated with disease and traits. Front Genet 2013;4:283.

35. Chen Z, Liu K, Yan Z, Xiang S, Sun Z. nc2Cancer: a database for cancer-associated human ncRNAs. Chin J Bioinformatics 2015;13:77-81.

36. Chen Y, Li C, Tan C, Liu X. Circular RNAs: a new frontier in the study of human diseases. J Med Genet 2016;53:359-65.

37. O.A.MJT. K. A small piece in the cancer puzzle: microRNAs as tumor suppressors and oncogenes. Oncogene 2006;25:96-188.

38. Hansen TB, Jensen TI, Clausen BH, Bramsen JB, Finsen B, Damgaard CK, et al. Natural RNA circles function as efficient microRNA sponges. Nature 2013;495:384.

39. Dong Y, He D, Peng Z, Peng W, Shi W, Wang J, et al. Circular RNAs in cancer: an emerging key player. J Hematol Oncol 2017;10:2. 
40. Chénard CA, Richard S. New implications for the QUAKING RNA binding protein in human disease. J Neurosci Res 2008;86:233-42.

41. Guarnerio J, Bezzi M, Jeong JC, Paffenholz SV, Berry K, Naldini MM, et al. Oncogenic role of fusion-circRNAs derived from cancer-associated chromosomal translocations. Cell 2016;165:289-302.

42. Meyerson M, Gabriel S, Getz G. Advances in understanding cancer genomes through second-generation sequencing. Nat Rev Genet 2010;11:685.

43. Huang G, Zhu H, Shi Y, Wu W, Cai H, Chen X. cir-ITCH plays an inhibitory role in colorectal cancer by regulating the Wnt/ $\beta$-catenin pathway. PloS One 2015;10:e0131225.

44. Padala RR, Karnawat R, Viswanathan SB, Thakkar AV, Das AB. Cancerous perturbations within the ERK, $\mathrm{PI} 3 \mathrm{~K} / \mathrm{Akt}$, and $\mathrm{Wnt} / \beta$-catenin signaling network constitutively activate inter-pathway positive feedback loops. Mol Biosyst 2017;13:830-40.

45. Weng W, Wei Q, Toden S, Yoshida K, Nagasaka T, Fujiwara T, et al. Circular RNA ciRS-7—a promising prognostic biomarker and a potential therapeutic target in colorectal cancer. Clin Cancer Res 2017; 23:3918-28.

46. Greene J, Baird A-M, Brady L, Lim M, Gray SG, McDermott R, et al. Circular RNAs: biogenesis, function and role in human diseases. Front Mol Biosci 2017;4:38.

47. Li F, Zhang L, Li W, Deng J, Zheng J, An M, et al. Circular RNA ITCH has inhibitory effect on ESCC by suppressing the Wnt/ $\beta$-catenin pathway. Oncotarget 2015;6:6001.

48. Wan L, Zhang L, Fan K, Cheng Z-X, Sun Q-C, Wang J-J. Circular RNA-ITCH suppresses lung cancer proliferation via inhibiting the Wnt/ $\beta$-catenin pathway. Biomed Res Int 2016;2016.

49. Wang K, Sun Y, Tao W, Fei X, Chang C. Androgen receptor (AR) promotes clear cell renal cell carcinoma (ccRCC) migration and invasion via altering the circHIAT1/miR-195-5p/29a-3p/29c-3p/CDC42 signals. Cancer let 2017;394:1-12.

50. Humphries B, Yang C. The microRNA-200 family: small molecules with novel roles in cancer development, progression and therapy. Oncotarget 2015;6:6472.

51. Noori-Daloii M, Alvandi E. Micro RNA: little but mysterious, and its use: a review article. The Journal of Faculty of Medicine, TUMS 2006;64:5-19.[In Persian]

52. Noori-Daloii MR, Nejatizadeh A. MicroRNA in disease and health: diagnostic and therapeutic potentials. Gene Therapy Development and Future Perspectives. Rijeka, Croatia: InTech; 2011. P.93-120.

53. Noori-Daloii M, Vand Rajabpour F. Roles of miRNAs in gene expression regulation, apoptosis, diagnosis and treatment of cancer. Medical Science Journal of Islamic Azad university-Tehran Medical Branch 2011;21.3:151-61. [In Persian]

54. Bhattacharya A, Cui Y. SomamiR 2.0: a database of cancer somatic mutations altering microRNA-ceRNA interactions. Nucleic Acids Res 2015;44:D1005-10.

55. Peng L, Yuan XQ, Li GC. The emerging landscape of circular RNA ciRS-7 in cancer. Oncol Rep 2015;33:2669-74.

56. Yu L, Gong X, Sun L, Zhou Q, Lu B, Zhu L. The circular RNA Cdr1as act as an oncogene in hepatocellular carcinoma through targeting miR-7 expression. PloS One 2016;11:e0158347.

57. Qin M, Liu G, Huo X, Tao X, Sun X, Ge Z, et al. Hsa_circ_0001649: a circular RNA and potential novel biomarker for hepatocellular carcinoma. Cancer Biomark 2016;16:161-9.

58. Shang X, Li G, Liu H, Li T, Liu J, Zhao Q, et al. Comprehensive circular RNA profiling reveals that hsa_circ_0005075, a new circular RNA biomarker, is involved in hepatocellular crcinoma development. Medicine 2016;95: e3811.

59. Dou Y, Cha DJ, Franklin JL, Higginbotham JN, Jeppesen DK, Weaver AM, et al. Circular RNAs are downregulated in KRAS mutant colon cancer cells and can be transferred to exosomes. Sci Rep 2016;6:37982.

60. Ye Q, Yao G, Zhang M, Guo G, Hu Y, Jiang J, et al. A novel ent-kaurane diterpenoid executes antitumor function in colorectal cancer cells by inhibiting Wnt/ $\beta$-catenin signaling. Carcinogenesis 2015;36:318-26.

61.Li P, Chen S, Chen H, Mo X, Li T, Shao Y, et al. Using circular RNA as a novel type of biomarker in the screening of gastric cancer. Clin Chim Acta 2015;444:132-6.

62. Chen J, Li Y, Zheng Q, Bao C, He J, Chen B, et al. Circular RNA profile identifies circPVT1 as a proliferative factor and prognostic marker in gastric cancer. Cancer Lett 2017;388:208-19. 
63. Zhong Z, Lv M, Chen J. Screening differential circular RNA expression profiles reveals the regulatory role of circTCF25-miR-103a-3p/miR-107-CDK6 pathway in bladder carcinoma. Sci Rep 2016;6:30919.

64. Qu S, Song W, Yang X, Wang J, Zhang R, Zhang Z, et al. Microarray expression profile of circular RNAs in human pancreatic ductal adenocarcinoma. Genom Data 2015;5:385-7.

65. Boeckel J-N, Jaé N, Heumüller AW, Chen W, Boon RA, Stellos K, et al. Identification and characterization of hypoxia-regulated endothelial circular RNA. Circ Res 2015: 117:884-90.

66. Tan WL, Lim BT, Anene-Nzelu CG, Ackers-Johnson M, Dashi A, See K, et al. A landscape of circular RNA expression in the human heart. Cardiovasc Res 2016;113:298-309.

67. Jakobi T, Czaja-Hasse LF, Reinhardt R, Dieterich C. Profiling and validation of the circular RNA repertoire in adult murine hearts. Genomics Proteomics Bioinformatics 2016;14:216-23.

68. Zhao Z, Li X, Gao C, Jian D, Hao P, Rao L, et al. Peripheral blood circular RNA hsa_circ_0124644 can be used as a diagnostic biomarker of coronary artery disease. Sci Rep 2017;7:39918.

69. Xu H, Guo S, Li W, Yu P. The circular RNA Cdr1as, via miR-7 and its targets, regulates insulin transcription and secretion in islet cells. Sci Rep 2015;5:12453.

70. You X, Vlatkovic I, Babic A, Will T, Epstein I, Tushev G, et al. Neural circular RNAs are derived from synaptic genes and regulated by development and plasticity. Nat Neurosci 2015;18:603.

71. Lukiw W. Circular RNA (circRNA) in Alzheimer's disease (AD). Front Genet 2013;4:307.

72.Panda AC, Abdelmohsen K, Gorospe M. RT-qPCR detection of senescence-associated circular RNAs. Methods Mol Biol 2017;1534:79-87.

73. Campisi J. Aging, cellular senescence, and cancer. Ann Rev Physiol 2013;75:685-705.

74. Lehmann SM, Krüger C, Park B, Derkow K, Rosenberger K, Baumgart J, et al. An unconventional role for miRNA: let-7 activates Toll-like receptor 7 and causes neurodegeneration. Nat Neurosci 2012;15:827.

75. Panda AC, Grammatikakis I, Kim KM, De S, Martindale JL, Munk R, et al. Identification of senescence-associated circular RNAs (SAC-RNAs) reveals senescence suppressor CircPVT1. Nucleic Acids Res 2016;45:4021-35.

76. Abbosh C, Birkbak NJ, Wilson GA, Jamal-Hanjani M, Constantin T, Salari R, et al. Phylogenetic ctDNA analysis depicts early-stage lung cancer evolution. Nature 2017;545:446.

77. Reid G, Pel M, Kirschner M, Cheng Y, Mugridge N, Weiss J, et al. Restoring expression of miR-16: a novel approach to therapy for malignant pleural mesothelioma. Ann Oncol 2013;24:3128-35. 